\title{
Influence of Disease Activity and Body Composition Parameters on Cross-Sectional Area of the Median Nerve in Acromegalic Patients
}

\author{
Ivana SÁGOVÁ ${ }^{1}$, Dušan PAVAI ${ }^{1}$, Daniela KANTÁROVÁ ${ }^{2}$, Dana HOLOVÁČOVÁ ${ }^{3}$, Martin \\ KUŽMA ${ }^{4}$, Juraj PAYER ${ }^{4}$, Peter VAŇUGA ${ }^{1}$
}

${ }^{1}$ Department of Endocrinology, National Institute of Endocrinology and Diabetology, Lubochňa, Slovakia, ${ }^{2} 1$ st Department of Internal Medicine, Jessenius Faculty of Medicine, Comenius University, University Hospital Martin, Martin, Slovakia, ${ }^{3} 1$ st Department of Internal Medicine, Faculty of Medicine, Comenius University, University Hospital Bratislava, Bratislava, Slovakia, ${ }^{4} 5$ th Department of Internal Medicine, Faculty of Medicine, Comenius University, University Hospital Bratislava, Bratislava, Slovakia

Received March 16, 2021

Accepted August 8, 2021

Epub Ahead of Print October 30, 2021

\section{Summary}

Carpal tunnel syndrome (CTS) is neuropathy that occurs due to compression of the median nerve in the carpal tunnel. Acromegaly is one of the important causes of CTS. The aim of this study was to examine median nerve with ultrasound in acromegalic patients and to assess the relationship with activity, duration of disease and body composition parameters. We prospectively examined the cross-sectional area (CSA) of the median nerve with high-resolution ultrasound in 107 acromegalic patients - control group (70 females and 37 males) and 107 healthy controls (70 females and 37 males) matched for age, gender, and BMI. Body composition parameters were assessed by dual-energy X-ray absorptiometry (DXA). The Student t-tests and Pearson correlation were used for data analysis. The cross sectional area of the median nerve was increased in acromegalic patients compared to controls $\left(11.9 \pm 4.8 \mathrm{~mm}^{2}\right.$ vs. $7.7 \pm 2.4 \mathrm{~mm}^{2}$, $\mathrm{P}<0.001)$. Positive correlation was found between IGF-1 levels and CSA in the acromegalic group ( $R=0.400, P<0.001)$. Relationship between CSA and duration of acromegaly was not confirmed. In acromegalic patients, BMI correlated with the CSA $(R=0.294, P=0.002)$. There was no significant difference in BMI, fat mass between the acromegalic and control group, but lean mass was higher in acromegalic patients compared with controls (54.8 \pm 13.3 vs. $51 \pm 11.6, \mathrm{P}=0.047$ ). Lean mass and LMI (total body lean mass/height) positively correlated with CSA in acromegalic patients $(\mathrm{R}=0.340, \mathrm{P}<0.001 ; \mathrm{R}=0.424, \mathrm{P}<0.001)$. No correlation was observed between fat mass and CSA of median nerve in all groups. We confirmed the enlargement of the median nerve in acromegalic patients. This enlargement is proportional to the degree of IGF-1 levels and is not dependent on the duration of the disease. The enlargement of the median nerve in acromegalic patients also depends on lean body mass and is not dependent on fat body mass.

\section{Key words}

Acromegaly - Body composition parameters - Cross sectional area of median nerve - Fat body mass - Lean body mass • Ultrasonography

\section{Corresponding author}

Ivana Ságová, Department of Endocrinology, National Institute of Endocrinology and Diabetology, Kollárová 282/3, 03491 L'ubochňa, Slovakia. Email: iva.sagova@gmail.com

\section{Introduction}

Acromegaly is a chronic progressive multisystem disorder seen in adults which is mainly caused by anterior pituitary tumours that secretes excessive amount of growth hormone $(\mathrm{GH})$, resulting in insulin like growth factor 1 (IGF-1) overproduction. Hormonal effect of GH and IGF-1 include overgrowth or edema of the parts of skeleton and other tissues such as cartilage, periosteum ligaments, synovial membrane and connective tissue. Peripheral neuropathy develops due to the compression of peripheral nerve around the growing muscle and skeletal system or due to edema (Milner 2018). The most common form of peripheral entrapment 
neuropathy in acromegaly is carpal tunnel syndrome (CTS). Generalised neuropathy is a much less recognised complication and only occasional reports have appeared (Milner 2018). The carpal tunnel syndrome occurs in approximately $20 \%$ to $64 \%$ of acromegalic patients at the time of diagnosis (Colao et al. 2004, Jenkins et al. 2000, Sasagawa et al. 2015). Median neuropathy in acromegaly have proposed various pathogenic mechanisms, including an increase in the amount of connective tissue in the carpal tunnel, demyelination of Schwann cells, bone or synovial overgrowth of the carpal bones, or an increase in the amount of extracellular fluid in the tunnel (Sasagawa et al. 2015). Several studies reported the predominant pathology of median neuropathy in acromegaly consisting of increased edema of the median nerve in the carpal tunnel, rather than extrinsic compression due to increased volume of the carpal tunnel contents (Killinger et al. 2010, Resmini et al. 2009, Kocak et al. 2015). The exact role of growth hormone and IGF-1 in the development of CTS in acromegaly is still unknown, however improvement in CTS occurs immediately after surgery or radiotherapy (Resmini et al. 2009, Kocak et al. 2015). Diagnosis of CTS is mostly based on clinical findings (Payam et al. 2014). Nerve Conduction Studies (NCS) are still the standard for CTS diagnosis, its sensitivity ranged from $49 \%$ to $86 \%$ and false negativity ranged between 16 and $34 \%$ (Jablecki et al. 1993, Azami et al. 2014). Other more recent reviews put the sensitivity at $85-90 \%$ and the specificity at $82-85 \%$ and recognize that electrophysiology studies alone should not be used as the standard for diagnosis (Werner 2013). Ultrasonography (US) is now well established as an alternative tool in the diagnosis of CTS (Azami et al. 2014, Beekman et al. 2003). US is a non-invasive, cost effective, available clinical method, which can be used to assess a number of parameters of the median nerve as size, vascularity and mobility (Mc Donagh et al. 2015). The use of US in the diagnosis of CTS has been demonostrated in number of studies showing that sensitivity and specificity are approaching that of electrophysiology studies (Mc Donagh et al. 2015, Ghasemi et al. 2011, Pinilla et al. 2008). Different studies demonstrated that cross sectional area (CSA) of the median nerve at the level of inlet of the carpal tunnel (level of pisiform bone) are significantly greater in CTS patients compared with healthy population (Dalili et al. 2011, Fu T et al. 2015, Kim et al. 2013). In previous studies, cut - off point of CSA at tunnel inlet in patients with CTS ranged from 6.5 to $15 \mathrm{~mm}^{2}$ (Pinilla et al. 2008, Fu T et al. 2015, Mohammadi et al. 2010). Median nerve enlargement CSA $\geq 10 \mathrm{~mm}^{2}$ at inlet of carpal tunnel is the most commonly used parameter to diagnose CTS on US (McDonagh et al. 2015, Holováčová et al. 2016). The aim of present study was to determine CSA of the median nerve at the level of pisiform bone using high resolution ultrasonography in acromegalic patients and to establish whether some relationship exists with activity and duration of disease and also with body composition parameters.

\section{Methods}

\section{Patients}

We prospectively examinated 107 acromegalic patients - control group ( 70 females and 37 males) and 107 healthy volunteers (70 females and 37 males) matched for sex, age and BMI, which served as a control group. The study was performed in National Institute of Endocrinology and Diabetology in Lubochňa, between December 2017 and December 2019. The study protocol was approved by regional medical ethics committee. Every study subject voluntarily signed an informed consent on study participation. The inclusion criteria for acromegalic patients was presence of acromegaly. Diagnosis of acromegaly was based on established criteria (Giustina et al. 2000).

Exclusion criteria for all individuals were as follows: no history of familial neuropathy, no history of alcohol consumption, no history of wrist trauma or neuropathies due to chronic renal failure, liver disease, pregnancy, cervical neuropathy, polyneuropathy and paraneoplastic inflammation. We also excluded patients with levels of thyroid stimulating hormone (TSH) higher than $5.00 \mathrm{mIU} / \mathrm{l}$ and patients suffering from diabetes mellitus. In all study subjects we performed anthropometric measurements including weight $(\mathrm{kg})$, height $(\mathrm{cm})$, body mass index (BMI) was calculated as weight in kilograms divided by square of height in meters. Pain, symptoms of paresthesia, weakness and numbness were questioned in the form of present/absent.

\section{Laboratory methods}

In all study subjects, we performed the battery of standard laboratory tests measuring blood count differential, creatinine and urea concentration, serum lipid profile, CRP level, liver enzymes, serum glucose, glycated hemoglobin, TSH, free T4 and vitamin B12. 
Blood samples were obtained at basal conditions after night - long fasting, between 7.30 - 8.00 am. Serum IGF-1 and GH levels were assessed by chemiluminescent immunometric assay (Immulite 2000, Siemens Healthcare Diagnostics Products Ltd., United Kingdom). Interassay co-efficient of variability (CV) is for IGF-1 between $3.0-7.6 \%$ and for $\mathrm{GH}$ between $6.5-6.6 \%$. Normal level for serum $\mathrm{GH}$ was $5 \mathrm{ng} / \mathrm{ml}$. Normal range of IGF-1 was sex and age - adjusted.

\section{Ultrasonography}

Ultrasonography was performed using 12-5 MHz linear array transducer (Hitachi-Hi Preirus ultrasound machine, Tokyo, Japan). All patients underwent ultrasonography of carpal tunnel. The patients were seated opposite to the sonographer and their wrists were placed in horizontal supine position on the examination table with fingers semiextended. The median nerve was examinated at the carpal tunnel inlet, between the pisiform bone and the scaphoid tubercle, where the distal volar crease is an external pisiform landmark. The median nerve was evaluated in the transverse plane; we also used a longitudinal view to confirm correct identification of the median nerve. The normal appearence of the median nerve is readily recognized as it consists of multiple hypoechoic bands, which are separated by hyperechoic lines corresponding to the epineurium (Watanabe et al. 2010). On transverse sonograms, the median nerve appears as an elliptic or oval outline. The CSA of the median nerve was calculated using the direct tracing method by outlining the perimeter just inside the hyperechoic epineurium, which marked the border of the median nerve, and the area within was measured as cross sectional area. Each measurement was performed 5 times and the mean value was used for analyses.

\section{Body composition measurements}

Body composition was measured by Dual Energy X-ray Absorptiometry (DXA) (Hologic Horizon A, Bedford, MA) using whole-body software version 13.6. Coefficient of variation was $0.78 \%$ for fat mass and $0.52 \%$ for lean mass. We measured total body fat mass $(\mathrm{kg})$, total body lean mass $(\mathrm{kg})$ and fat percentage $(\%)$. We calculated fat mass index $(\mathrm{FMI})=$ total body fat mass/ height $\left(\mathrm{kg} / \mathrm{m}^{2}\right)$ and lean mass index $(\mathrm{LMI})=$ total body lean mass $/$ height $\left(\mathrm{kg} / \mathrm{m}^{2}\right)$.

\section{Statistical analysis}

All statistical analyses were performed using IBM SPSS version 25 (IBM SPSS Statistics, IBM
Corporation, IL, USA). Statistical power was calculated using the G*Power v. 3.0.1 software. Qualitative variables were expressed using absolute and relative abilities. Quantitative variables were expressed as number of measurements, mean and \pm standard deviation (SD). The Student t-test was used to compare groups. Correlation analyses were performed using Pearson correlation coefficient and its significance was tested by the respective test. Normality test passed for all variables. In each statistical test performed, the criteria for statistical significance was $\mathrm{p} \leq 0.05$. All tests were two-tailed.

\section{Results}

One hundred and seven acromegalic patients (70 [65.42\%] females and 37 [34.58\%] males) were included in the study. The mean age of acromegalic patients was 56.4 years. The age-, sex-, and BMI matched controls consisted of 107 (70 [65.42\%] females and 37 [34.58\%] males) healthy subjects with mean age 57.3 years. Baseline characteristics of subjects are summarized in Table 1.

Association between duration/activity of acromegaly and CSA of the median nerve

The average duration of acromegaly was $\varnothing 11$ years, baseline serum level of IGF-1 was ø $249.9 \mathrm{ng} / \mathrm{ml}$ and serum level of $\mathrm{GH}$ was ø $2.6 \mathrm{ng} / \mathrm{ml}$ in study group. Serum levels of GH and IGF-1 were significantly higher in acromegalic patients compared with controls (Table 1). The cross sectional area of the median nerve was increased in acromegalic patients compared with controls $\left(11.9 \pm 4.8 \mathrm{~mm}^{2}\right.$ vs. $7.7 \pm 2.4 \mathrm{~mm}^{2}$, $\mathrm{P}<0.001$ ) (Table 1).

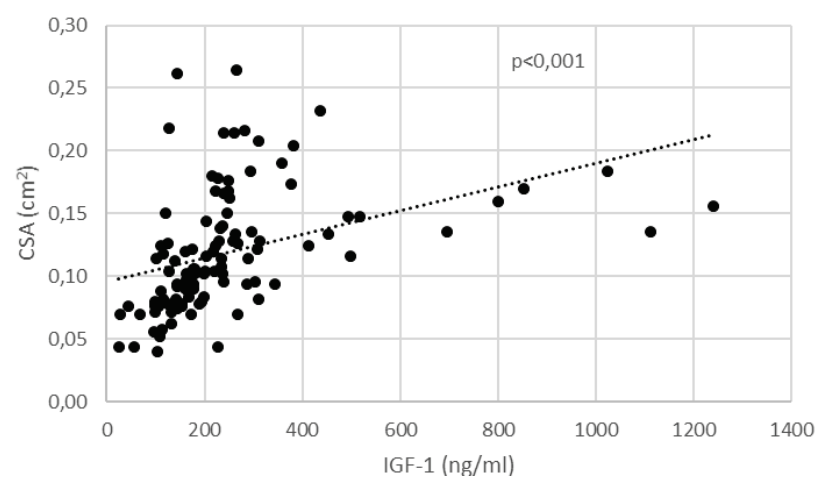

Fig. 1. Correlation between IGF-1 and CSA of the median nerve in acromegalic patients. CSA: cross sectional area, IGF -1: insulin-like-growth factor 1 
Table 1. Baseline characteristics of subjects

\begin{tabular}{|c|c|c|c|}
\hline Characteristics & Study group $(n=107)$ & Control group $(n=107)$ & p-value \\
\hline $\operatorname{Sex}(M / F)$ & $37 / 70$ & $37 / 70$ & \\
\hline Age (year) & $56.4 \pm 12.4$ & $57.3 \pm 13.0$ & $\mathrm{~ns}$ \\
\hline$M / F$ & $51.8 \pm 11.5 / 58.8 \pm 12.1$ & $52 \pm 10.5 / 58.9 \pm 11.5$ & \\
\hline Duration of disease (year) & $11 \pm 10.1$ & - & \\
\hline$G H(n g / m l)$ & $2.6 \pm 5.7$ & $0.37 \pm 0.5$ & $<0.001$ \\
\hline$I G F-1(\mathrm{ng} / \mathrm{ml})$ & $249.9 \pm 173.3$ & $134 \pm 48.6$ & $<0.001$ \\
\hline$M / F$ & $288.8 \pm 202.2 / 229.4 \pm 154.7$ & $138 \pm 40.7 / 134 \pm 47.2$ & \\
\hline \multicolumn{4}{|c|}{ Anthropometric measurements } \\
\hline Height $(\mathrm{cm})$ & $171 \pm 8.9$ & $170.3 \pm 9.1$ & ns \\
\hline$M / F$ & $179.3 \pm 7.1 / 166.6 \pm 6.2$ & $176.1 \pm 7.8 / 165.8 \pm 6.7$ & \\
\hline Weight (kg) & $86.4 \pm 18.8$ & $84.5 \pm 18$ & ns \\
\hline$M / F$ & $99.4 \pm 16.0 / 79.6 \pm 16.4$ & $93.6 \pm 16.7 / 79.8 \pm 16.9$ & \\
\hline$B M I\left(\mathrm{~kg} / \mathrm{m}^{2}\right)$ & $29.5 \pm 5.8$ & $29.7 \pm 5.1$ & ns \\
\hline$M / F$ & $31.0 \pm 5.1 / 28.7 \pm 6.0$ & $30.2 \pm 4.2 / 29.7 \pm 5.8$ & \\
\hline \multicolumn{4}{|l|}{ Ultrasonography } \\
\hline CSA of $n$. medianus $\left(\mathrm{mm}^{2}\right)$ & $11.9 \pm 4.8$ & $7.7 \pm 2.4$ & $<0.001$ \\
\hline$M / F$ & $13.2 \pm 4.7 / 11.2 \pm 4.7$ & $7.9 \pm 1.4 / 7.5 \pm 2.4$ & \\
\hline \multicolumn{4}{|l|}{ DXA measurements } \\
\hline Total fat $(\%)$ & $35.7 \pm 6.9$ & $36.7 \pm 7.8$ & ns \\
\hline$M / F$ & $29.6 \pm 5.6 / 39 \pm 5.1$ & $28.8 \pm 4.2 / 40.8 \pm 5.4$ & \\
\hline Fat mass (kg) & $31.8 \pm 9.7$ & $31.9 \pm 10.2$ & ns \\
\hline$M / F$ & $30.6 \pm 9.3 / 32.5 \pm 9.9$ & $28.6 \pm 7.8 / 34.4 \pm 10.5$ & \\
\hline Lean mass (kg) & $54.8 \pm 13.3$ & $51 \pm 11.6$ & 0.047 \\
\hline$M / F$ & $68.7 \pm 10.0 / 47.4 \pm 7.8$ & $62.4 \pm 12 / 42.7 \pm 9.8$ & \\
\hline$F M I\left(\mathrm{~kg} / \mathrm{m}^{2}\right)$ & $11 \pm 3.6$ & $11.3 \pm 4.0$ & $\mathrm{~ns}$ \\
\hline$M / F$ & $9.6 \pm 3.1 / 11.7 \pm 3.6$ & $8.6 \pm 2.4 / 12.6 \pm 4.1$ & \\
\hline$L M I\left(\mathrm{~kg} / \mathrm{m}^{2}\right)$ & $18.5 \pm 3.5$ & $16.9 \pm 2.8$ & 0.039 \\
\hline$M / F$ & $21.4 \pm 3 / 17 \pm 2.9$ & $19.7 \pm 2.7 / 15 \pm 2.4$ & \\
\hline
\end{tabular}

Data is presented as mean $\pm \mathrm{SD}$ (standard deviation), level of significance was set at $* \mathrm{p} \leq 0.05, \mathrm{GH}$ : growth hormone, IGF-1: insulinlike-growth factor 1, BMI: body mass index, CSA: cross sectional area, DXA: dual-energy X-ray, absorptiometry, FMI: fat mass/height index, LMI: lean mass/height index

Positive correlation was found between the serum levels of IGF-1 and CSA of the median nerve in the study group ( $\mathrm{R}=0.400, \mathrm{P}<0.001)$ (Fig. 1). Relationship between CSA of the median nerve and serum levels of GH, duration of acromegaly was not confirmed (Table 2).

Forty-eight acromegalic patients had CSA of the median nerve greater than $11 \mathrm{~mm}^{2}$. In twenty-four acromegalic patients, clinical signs (e.g. pain, weakness, paresthesia and numbness) of CTS were reported. Eighteen patients $(37.5 \%)$ with symptoms of CTS had a CSA of median nerve greater than $11 \mathrm{~mm}^{2}$. Thirty acromegalic patients $(62.5 \%)$ with median nerve greater than $11 \mathrm{~mm}^{2}$ were asymptomatic of CTS. The CSA of the median nerve was increased in symptomatic patients compared with asymptomatic patients $\left(14.6 \pm 2.8 \mathrm{~mm}^{2} \mathrm{vs}\right.$. $\left.12.8 \pm 1.7 \mathrm{~mm}^{2}, \mathrm{P} 0.019\right)$

Association between body composition parameters and CSA of the median nerve

BMI weakly correlated with CSA of the median nerve in the study group ( $\mathrm{R}=0.294, \mathrm{P}=0.002$ ) (Fig. 2). There was no statistically significant difference in BMI, fat mass between the study and the control group, but lean mass was higher in acromegalic patients compared with controls $(54.8 \pm 13.3$ vs. $51 \pm 11.6, \mathrm{P}=0.047)$ (Table 1). Lean mass and LMI (total body lean mass/ height) positively correlated with $\mathrm{CSA}$ in acromegalic patients $(\mathrm{R}=0.340, \mathrm{P}<0.001 ; \mathrm{R}=0.424, \mathrm{P}<0.001)$ (Fig. 3). No correlation was observed between fat mass, FMI and CSA of the median nerve in all groups (Table 2). 
Table 2. Correlation between duration / activity of acromegaly, anthropometric parameters, body composition parameters and CSA of the median nerve in acromegalic patients

\begin{tabular}{lcc}
\hline & \multicolumn{2}{c}{ CSA of the median nerve } \\
& $\begin{array}{c}\text { R-value } \\
\text { (Pearson correlation coefficient) }\end{array}$ & P-value \\
\hline Duration of acromegaly (year) & -0.031 & 0.754 \\
GH $(\mathrm{ng} / \mathrm{ml})$ & 0.042 & 0.668 \\
IGF- $1(\mathrm{ng} / \mathrm{ml})$ & 0.400 & $<0.001$ \\
Weight $(\mathrm{kg})$ & 0.261 & 0.007 \\
Height $(\mathrm{cm})$ & 0.034 & 0.728 \\
BMI $\left(\mathrm{kg} / \mathrm{m}^{2}\right)$ & 0.294 & 0.002 \\
Fat mass $(\mathrm{kg})$ & 0.042 & 0.668 \\
Lean $\mathrm{mass}(\mathrm{kg})$ & 0.340 & $<0.001$ \\
FMI $\left(\mathrm{kg} / \mathrm{m}^{2}\right)$ & 0.045 & 0.645 \\
LMI $\left(\mathrm{kg} / \mathrm{m}^{2}\right)$ & 0.424 & $<0.001$ \\
\hline
\end{tabular}

Level of significance was set at $* \mathrm{p} \leq 0.05, \mathrm{CSA}$ : cross sectional area, GH: growth hormone, IGF-1: insulin-like-growth factor 1 , BMI: body mass index, FMI: fat mass/height index, LMI: lean mass/height index

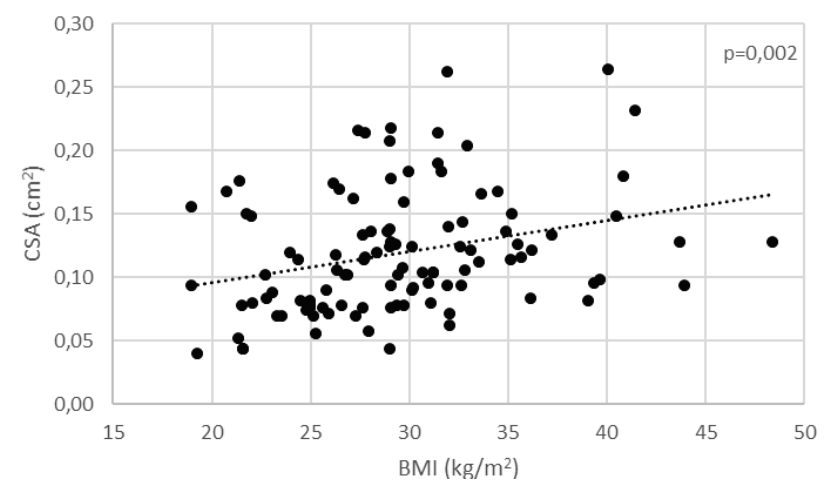

Fig. 2. Correlation between BMI and CSA of the median nerve in acromegalic patients. CSA: cross sectional area, BMI: body mass index

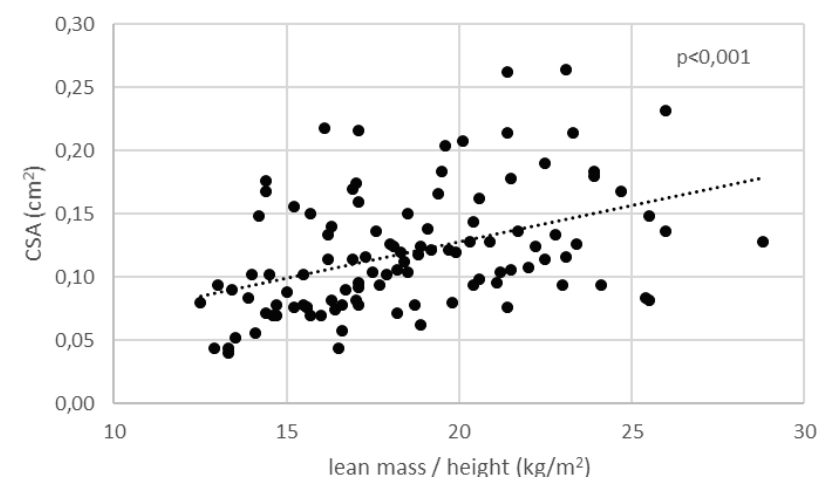

Fig. 3. Correlation between lean mass/height and CSA of the median nerve in acromegalic patients. CSA: cross sectional area

\section{Discussion}

Carpal tunnel syndrome (CTS) is common peripheral neuropathy in acromegaly. The pathological mechanisms of peripheral nerve abnormalities in acromegaly remain unclear (Resmini et al. 2009, Oktayoglu et al. 2015). Ultrasonography allowed an accurate and reliable depiction of the median nerve based on the established criteria (Tagliafico et al. 2007). In present study, we performed measurement of CSA of the median nerve at the level of pissiform bone using high - resolution ultrasound in acromegalic patients. Previous studies reported greater median nerve in acromegalic patients in comparison to healthy controls (Resmini et al. 2009, Kocak et al. 2015, Tagliafico et al. 2008). In our study we confirmed enlargement of the median nerve in acromegalic patients based on criterion that CSA of the median nerve over $10 \mathrm{~mm}^{2}$ at the pisiforme axis is the most used parameter for diagnose of CTS with a sensitivity higher than 97.9\% (McDonagh et al. 2015). Forty-eight acromegalic patients had CSA of the median nerve greater than $11 \mathrm{~mm}^{2}$. Thirty of these patients were asymptomatic of CTS. In 24 acromegalic patients, clinical signs (e.g. pain, weakness, paresthesia and numbness) of CTS were reported. Eighteen of them had a CSA measurement greater than $11 \mathrm{~mm}^{2}$, which is considered pathognomonic for CTS. CTS occurs with a prevalence of $64 \%$ in patients with sensory disturbances (Colao et al. 2004, Jenkins et al. 2000, Kaneyama et al. 1993). Even if asymptomatic, most patients with acromegaly have subclinical functional abnormalities detected on NCS (Kaneyama et al. 1993). The CSA of the median nerve in acromegalic patients 
positively correlated with concentration of IGF-1 in our study. Tagliafico et al. reported the same positive impact of IGF-1 on CSA of the median nerve in their study (Tagliafico et al. 2008). On the other hand Kocak et al. in their study on 38 acromegalic patients did not confirm this association (Kocak et al. 2015). The exact role of IGF-1 in pathology of CTS in acromegaly is still unknown. GH and IGF-1 interfere to the pathogenesis of CTS by several effects. GH and IGF-1 stimulates protein synthesis, differentiation and proliferation of muscle cells, chondrocytes and osteoblasts (Xiao et al. 2019). This process promotes skeletal growth and soft tissue enlargement which can cause the compression of median nerve in CTS. Another effect of GH reported in recent study is increased activity of epithelial sodium channel and this could contribute to the volume expansion and soft tissue manifestation (Lugo at el. 2012). The major pathogenetic factor for CTS of median nerve in acromegaly seems to be the increased edema of median nerve, but an increase in connective tissue, demyelination of Schwann cells, an increase in extracellular fluid of the carpal bones and bony or synovial overgrowth of carpal bones can be involved as well (Killinger et al. 2010, Resmini et al. 2009, Kocak et al. 2015, Lugo et al. 2012, Laike et al. 2020). These predominant pathophysiological mechanisms of the median neuropathy in acromegaly was supported by the study of Jenkins et al. (2000), who reported the occurrence of increased nerve size with increased signal intensity on $\mathrm{T}-2$ weighted magnetic resonance images as a sign of increased edema of the median nerve. He also described rapid reduction of nerve size after levels of circulating growth hormone and IGF-1 were decreased (Jenkins et al. 2000). This was also confirmed by ultrasonographic studies showing that acromegaly was associated with edema of not only the median nerve but also with ulnar nerve (Tagliafico et al. 2008). Patients with active acromegaly have generalized visceral edema related to the effect of GH on the distal kidney, where it increases epithelial sodium channel activity and stimulates sodium reabsorption (Kamenický et al. 2014). Additionally we examined the influence of body composition parameters on the CSA of the median nerve. We confirmed a positive correlation between CSA of the median nerve and BMI in the study group. Several studies have confirmed the same results, but these studies were performed on the general population (Sharifi et al. 2008, Mondelli et al. 2016, Shiri et al. 2015). In acromegaly GH and IGF-1 excess is associated with alterations in body composition, including an increase in body water, lean body mass and a reduction in body fat. According to these facts we performed body composition measurement using DXA. DXA divides body composition into fat, bone mineral and lean mass. Lean mass includes mass of skeletal muscle, organs and soft tissue (including tissue water). In our study, no correlation was found between CSA of the median nerve and fat mass in all groups but we found a positive correlation between CSA of the median nerve and lean mass and also with calculated LMI in acromegalic patients. GH has an anabolic effect on skeletal muscle, including suppression of locally synthesized myostatin and stimulation of protein synthesis (Moller et al. 2003, Katznelson 2009). On the other hand, GH has a lipolytic effect resulting in a reduction in adipose tissue and a sodium retention effect resulting in an increase in total body water and extracellular water. Several studies confirmed higher lean body mass in acromegalic patients compared to controls using DXA scans (Gibney et al. 2009, Kaji et al. 2001, Freda et al. 2009). Measurement of lean mass in acromegaly using DXA has limitation, because DXA cannot reliably differentiate water vs. protein. Several studies have confirmed the expansion of total body water (TBW) and extracellular water (ECW) in acromegalic patients, leading authors of these studies to conclude that increased soft tissue mass hydration and not skeletal muscle was the cause of increased lean mass in acromegaly (Gibney et al. 2009, Reid et al. 2015, Füchtbauer et al. 2017). These studies were performed by several techniques including isotopic dilution. Another studies have examined lean body mass using total body potassium for assessing body cell mass (BCM) but results have been conflicting in acromegaly (Pirlich et al. 2003, Landin et al. 1993). Studies examining effect of GH on protein synthesis confirmed anabolic effects of acromegaly on lean body mass (Gibney et al. 2009, Velloso et al. 2008, Viral et al. 2013). Despite the increase in protein synthesis in acromegaly, skleletal muscle may be functionally weaker. Examinations performed on skeletal muscle mass in acromegaly patients by biopsy confirmed hypertrophy of type 1 and atrophy of type 2 muscle fibers (Freda et al. 2009, Madsen et al. 2012, Brumback et al. 1983). These data suggest that acromegaly results in changes in skeletal muscle function that do not clearly correlate with the degree of change in lean body mass (Madsen et al. 2012, Brumback et al. 1983). Our results and also previous research suggest that edema of the median nerve could be dominant pathophysiological mechanism of CTS in 
acromegaly although other causes such as soft tissue enlargement and skeletal growth can participate as well. Further research is necessary to determine these relationships better. To our knowledge this is the first study investigating the influence of body composition parameters using DXA scan on CSA of the median nerve in acromegalic patients.

\section{Limitations}

Although optimum care had been tried by the researcher in this study, still some limitations exist. The study is limited by a relatively small sample size because of low incidence of the disease and there were gender differences in number of patients present. The study was also designed as a cross sectional therefore subject to selection bias.

\section{Conclusion}

In our study, we confirmed the enlargement of median nerve in acromegalic patients. This enlargement is proportional to the degree of IGF-1 levels and is not dependent on the duration of disease. According to our findings the enlargement of median nerve in acromegaly also depends on body composition. We confirmed positive correlation between CSA of the median nerve and BMI in acromegalic patients. CSA of the median nerve significantly correlates with lean mass but we have not found any correlation with fat mass.

\section{Conflict of Interest}

There is no conflict of interest.

\section{Acknowledgements}

This study received no financial support.

\section{References}

AZAMI A, MALEKI N, ANARI H, IRANPARVAR MA, KALANTARHORMOZI M, TAVOSI Z: The diagnostic value of ultrasound compared with nerve conductionvelocity in carpla tunnel syndrome. Int J Rheum Dis 17 : 612-620, 2014. https://doi.org/10.1111/1756-185x.12310

BEEKMAN R, VISSER L. Sonography in the diagnosis of carpal tunnel syndrome: a critical review of the literature. Muscle Nerve 27: 26-33, 2003. https://doi.org/10.1002/mus.10227

BRUMBACK RA, BARR CE: Myopathy in acromegaly. A case study. Pathol Res Pract 177: 41-46, 1983.

COLAO A, FERONE D, MARZULLO P, LOMBARDI G: Systemic complications of acromegaly: epidemiology, pathogenesis and management. Endocr Rev 25: 102-152, 2004. https://doi.org/10.1210/er.2002-0022

DALILI AR, MARDANI KM, ALIZADEH A, HATAMIAN HR, HOSEININEJAD N, PEYRAZM H: Comparison between sonography and electrodiagnostic testing in the diagnosis of carpal tunnel syndrome. Anesthesiol Pain 2: 43-51, 2011.

FREDA PU, SHEN W, REYES-VIDAL CM, GEER EB, ARIAS-MENDOZA F, GALLAGHER D, HEYMSFIELD SB: Skeletal muscle mass in acromegaly assessed by magnetic resonance imaging and dual-photon $x$-ray absorptiometry. J Clin Endocrinol Metab 94: 2880-2886, 2009. https://doi.org/10.1210/jc.2009-0026

FU T, CAO M, LIU F, ZHU J, YE D, FENG X, XU Y, WANG G, BAI Y: Carpal tunnel syndrome assesment with ultrasonography: value of inlet-to-outlet median nerve arearation in patients versus healthy volunteers. Plos one 10, e0116777, 2015. https://doi.org/10.1371/journal.pone.0116777

FÜCHTBAUER L, OLSSON DS, BENGTSSON BÅ, NORRMAN LL, SUNNERHAGEN KS, JOHANNSSON G: Muscle strength in patients with acromegaly at diagnosis and during long-term follow-up. Eur J Endocrinol 177: 217-226, 2017. https://doi.org/10.1530/eje-17-0120

GHASEMI-ESFE A, KHALILZADEH O, MAZLOUMI M, VAZIRI-BOZORG SM, KAHNOUJI H, RAHMANI M: Combination of high-resolution and color Doppler ultrasound in diagnosis of carpal tunnel syndrome. Acta Radiol 52: 191-197, 2011. https://doi.org/10.1258/ar.2010.100299

GIBNEY J, WOLTHERS T, BURT MG, LEUNG KC, UMPLEBY AM, HO KK: Protein metabolism in acromegaly: differential effects of short- and long-term treatment. J Clin Endocrinol Metab 92: 1479-1484, 2007. https://doi.org/10.1210/jc.2006-0664 
GIUSTINA A, BARKAN A, CASANUEVA FF, CAVAGNINI F, FROHMAN L, HO K, VELDHUIS J, WASS J, VON WERDER K, MELMED S: Criteria for cure of acromegaly: a consensus statement. J Clin Endocrinol Metab 85: 526-529, 2000. https://doi.org/10.1210/jcem.85.2.6363

HOLOVÁČOVÁ D, KUŽMA M, KOLLINGER Z, PAYER J: Cross sectional area of th median nerve is increased in primary autoimmune hypothyroidism and decrease upon treatment with thyroxine. Eur J Endocrinol 175: 265-270, 2016. https://doi.org/10.1530/eje-16-0397

JABLECKI CK, ANDARY MT, SO YT, WILKINS DE, WILLIAMS FH: Literature review of the usefulness of nerve conduction studies and electromyography for the evaluation of patients with carpal tunnel syndrome. AAEM Quality Assurance Committee. Muscle Nerve 16: 1392-1414, 1993. https://doi.org/10.1002/mus.880161220

JENKINS PJ, SOHAIB SA, AKKER S, PHILLIPS RR, SPILLANE K, WASS JA, MONSON JP, GROSSMAN AB, BESSER GM, REZNEK RH: The pathology of median neuropathy in acromegaly. Ann Intern Med 133: 197-201, 2000. https://doi.org/10.7326/0003-4819-133-3-200008010-00011

KAJI H, SUGIMOTO T, NAKAOKA D, OKIMURA Y, KAJI H, ABE H, CHIHARA K: Bone metabolism and body composition in Japanese patients with active acromegaly. Clin Endocrinol (Oxf) 55: 175-181, 2001. https://doi.org/10.1046/j.1365-2265.2001.01280.x

KAMENICKÝ P, MAZZIOTTI G, LOMBES M, GIUSTINA A, CHANSON P: Growth hormone, insulin-like growth factor -1 , and the kidney: pathophysiological and clinical implications. Endocr Rev 35: 234-281, 2014. https://doi.org/10.1210/er.2013-1071

KANEYAMA S, TANAKA R, HASEGAWA A, TAMURA T, KUROKI M: Subclinical carpal tunnel syndrome in acromegaly. Neurol Med Chir 3: 547-551, 1993. https://doi.org/10.2176/nmc.33.547

KATZNELSON L: Alterations in body composition in acromegaly. Pituitary 12: 136-142, 2009. https://doi.org/10.1007/s11102-008-0104-8

KILLINGER Z, PAYER J, LAZÚROVÁ I, IMRICH R, HOMÉROVÁ Z, KUŽMA M, ROVENSKÝ J: Arthropathy in acromegaly. Rheum Dis Clin North Am 36: 713-720, 2010. https://doi.org/10.1016/j.rdc.2010.09.004

KIM J, KIM M, KO Y: Correlating ultrasound findings of carpal tunnel syndrome with nerve conduction studies. Muscle Nerve 48: 905-910, 2013. https://doi.org/10.1002/mus.23841

KOCAK M, CIVAN N, KARKUCAK M, CAPKIN E, GARIPOGLU M, CAN I, KARACA A, TASDELEN M, AYAR A: Ultrasonographic assessment of soft tissues in patients with acromegaly. Arch Rheumatol 30: 138-143, 2015. https://doi.org/10.5606/archrheumatol.2015.5158

LAKE J, CHAIDURUN S: Spade phalanx sign of acromegaly. BMJ 368: 2020. https://doi.org/10.1136/bmj.m691

LANDIN K, PETRUSON B, JAKOBSSON KE, BENGTSOON BA: Skeletal muscle sodium and potassium changes after successful surgery in acromegaly: relation to body composition, blood glucose, plasma insulin and blood pressure. Acta Endocrinol (Copenh) 128: 418-422, 1993. https://doi.org/10.1530/acta.0.1280418

LUGO G, PENA L, CORDIDO F: Clinical manifestation and diagnosis of acromegaly. Int J Endocrinol: Article ID 540398, 2012. https://doi.org/10.1155/2012/540398

MADSEN M, KRUSENSTJERNA-HAFSTROM T, MOLLER L, CHRISTENSEN B, VENDELBO MH, PEDERSEN SB, FRYSTYK J, JESSEN N, HANSEN TK, JORGENSEN HS, FLYVBERG A, JORGENSEN JO: Fat content in liver and skeletal muscle changes in a reciprocal manner in patients with acromegaly during combination therapy with a somatostatin analog and a GH receptor antagonist: a randomized clinical trial. J Clin Endocrinol Metab 97: 1227-1235, 2012. https://doi.org/10.1210/jc.2011-2681

MCDONAGH C, ALEXANDER M, KANE D: The role of ultrasound in the diagnosis and management of carpal $\begin{array}{llllll}\text { tunnel syndrome: a new paradigm. Rheumatology } 54: 19-24, & 2015 .\end{array}$ https://doi.org/10.1093/rheumatology/keu275

MILNER A: Acromegaly and gigantism. S Afr Med J 24: 62-66, 2018.

MOHAMMADI A, AFSHAR A, ETEMADI A, MASOUDI S, BAGHIZADEH A: Diagnostic value of cross-sectional area of the median nerve in grading severity of carpal tunnel syndrome. Arch Iran Med 13: 516-521, 2010.

MOLLER J: Effects of growth hormone on fluid homeostasis. Clinical and experimental aspects. Growth Horm IGF Res. 13: 55-74, 2003. https://doi.org/10.1016/s1096-6374(03)00011-x 
MONDELLI M, FARIOLI A, MATTIOLI S, ARETINI A, GIAŃANNESCHI F, GRECO G, CURTI S: Associations between body anthropometric measures and severity of carpal tunnel syndrome. Arch Phys Med Rehabil 9: 1456-1464, 2016. https://doi.org/10.1016/j.apmr.2016.03.028

OKTAYOGLU P, NAS K, KILINC F, TASDEMIR N, BOZKURT M, YILDIZ I: Assessment of the presence of carpal tunnel syndrome in patients with diabetes mellitus, hypothyroidism and acromegaly. J Clin Diagnostic Res 9: 14-18, 2015. https://doi.org/10.7860/jcdr/2015/13149.6101

PAYAM S, MAHROOZ M, GHAJARZADEH M, MIRI S, PARHIZGAR E, EMAMI-RAZAVI SH: The best cutoff point for median nerve cross sectional area at the level of carpal tunnel inlet. Acta Medica Iranica 52: 613-618, 2014.

PINILLA I, MARTIN-HERVAS C, SORD G, SANTIAGO S: The usefulness of ulrasonography in the diagnosis of carpal tunnel syndrome. J Hand Surg Eur 33: 43-59, 2008.

PIRLICH M, SCHUTZ T, OCKENGA J, BIERING H, SCHMIDT B, ERTL S, PLAUTH M, LOCHS H: Improved assessment of body cell mass by segmental bioimpedance analysis in malnourished subjects and acromegaly. Clin Nutr 22: 167-174, 2003. https://doi.org/10.1016/j.clnu.2004.01.002

REID TJ, JIN Z, SHEN W, REYES-VIDAL CM, FERNANDEZ JC, BRUCE JN, POST KD, FREDA PU: IGF-1 levels across the spectrum of normal to elevated in acromegaly: relationship to insulin sensitivity, markers of cardiovascular risk and body composition. Pituitary 18: 808-819, 2015. https://doi.org/10.1007/s11102-0150657-2

RESMINI E, TAGLIAFICO A, NIZZO R, BIANCHI F, MINUTO F, DERCHI L, MARTINOLI C, FERONE D: Ultrasound of peripheral nerves in acromegaly: changes at 1-year follow-up. Clin Endocrinol (Oxf) 71: 220-225, 2009. https://doi.org/10.1111/j.1365-2265.2008.03468.x

SASAGAWA Y, TACHIBANA O, DOAI M, TONAMI H, IIZUKA H: Median nerve conduction studies and wrist magnetic resonance imaging in acromegalic patients with carpal tunnel syndrome. Pituitary 18: 695-700, 2015. https://doi.org/10.1007/s11102-015-0642-9

SHARIFI MA, YAZDCHI MM, AYRAMLOU H, HEIDARI P, SALAVATI A, ZARRINTAN S: Assessment of body mass index and hand anthropometric measurements as independent risk factors for carpal tunnel syndrome. Folia Morphol (Warsz) 67: 36-42, 2008.

SHIRI R, POURMEMARI MH, FALAH-HASSANI K, VIIKARI-JUNTURA E: The effect of excess body mass on the risk of carpal tunnel syndrome: a meta-analysis of 58 studies. Obes Rev 16: 1094-1104, 2015. https://doi.org/10.1111/obr.12324

TAGLIAFICO A, RESMINI E, NIZOO R, BIANCHI F, MINUTO F, FERONE D, MARTINOLI C: Ultrasound measurement of median and ulnar nerve cross-sectional area in acromegaly. J Clin Endocrinol Metab 93: 905-909, 2008. https://doi.org/10.1210/jc.2007-1719

TAGLIAFICO A, RUBINO M, AUTOURI A, BIANCHI S, MARTINOLI C. Wrist and hand ultrasound. Seminars in Musculoskeletal Radiology 11: 95-104, 2007. https://doi.org/10.1055/s-2007-1001875

VELLOSO CP: Regulation of muscle mass by growth hormone and IGF-I. Br J Pharmacol 154: 557-568, 2008.

VIRAL CH, HO K: Action of GH on skeletal muscle function: molecular and metabolic mechanisms, J Mol Endocrinol 52: 107-123, 2013.

WATANABE T, ITO H, SEKINE A, KATANO Y, NISHIMURA, KATO Y, TAKEDA J, SEISHIMA M, MTSUOKA T: Sonographic evaluation of the peripheral nerve in diabetic patients: the relationship between nerve conduction studies, echo intensity and cross-sectional area. J Ultrasound Med 29: 697-708, 2010. https://doi.org/10.7863/jum.2010.29.5.697

WERNER R: Electrodiagnostic evaluation of carpal tunnel syndrome and ulnar neuropathy. PM R 5: S14-S21, 2013. https://doi.org/10.1016/j.pmrj.2013.03.027

XIAO B, LIU F, LU J CH, CEN F, PEI W N, YANG X CH: IGF-1 deletion affects renal sympathetic nerve activity, left ventricular dysfunction, and renal function in DOCA-salt hypertensive mice. Physiol Res 68: 209-217, 2019. https://doi.org/10.33549/physiolres.933918 